\title{
Growth hormone deficiency during puberty reduces adult bone mineral density
}

\author{
S L Hyer, D A Rodin, J H Tobias, A Leiper, S S Nussey
}

St George's Hospital Medical School, London,

Department of

Biochemical Medicine

$S$ L Hyer

D A Rodin

S S Nussey

Department of

Histopathology

J H Tobias

Department of

Hospital for

Sick Children,

London

A Leiper

Correspondence to:

Dr $S$ L Hyer,

Department of

Biochemical Medicine,

St George's Hospital

Medical School,

Medical School,

Cranmer Terrace,
London SW 17 ORE

Accepted 15 July 1992
Haematology,

\begin{abstract}
Bone mineral density (BMD) was evaluated by dual energy $x$ ray absorptiometry in 60 adults (33 males, 27 females; aged 50, range 23-76 years) who were growth hormone deficient from various causes for 10.4 (1-31) years. Adult patients who had acquired growth hormone deficiency before completion of puberty had significantly reduced mean (SEM) BMD compared with age matched healthy controls at the lumbar spine: $0.87(0.09) v$ $1.20(0.03) \mathrm{g} / \mathrm{cm}^{2}$, femoral neck: $0.81(0.06) v$ $1.08(0.04) \mathrm{g} / \mathrm{cm}^{2}$, and Ward's triangle: 0.68 $(0.07) v 1.04(0.05) \mathrm{g} / \mathrm{cm}^{2}$. These values were also reduced compared with those of patients who had received human growth hormone during puberty. Untreated growth hormone deficiency when present during puberty results in reduced adult bone density.
\end{abstract}

(Arch Dis Child 1992;67:1472-4)

Little is known about the long term skeletal consequences of growth hormone deficiency other than reduced linear growth. Its importance for proper skeletal maturation has long been recognised as indicated by delayed bone age in growth hormone deficient children. ${ }^{1}$ Lack of growth hormone during puberty when bone mineral density (BMD) is normally rapidly increasing ${ }^{2}{ }^{3}$ could result in severe osteopenia in adult life but this has not been specifically addressed in previous studies. We have investigated BMD in adults with growth hormone deficiency with special emphasis on those in

Clinical details of patients with growth hormone deficiency present during puberty

\begin{tabular}{|c|c|c|c|c|c|}
\hline $\begin{array}{l}\text { Patient } \\
\text { No }\end{array}$ & Sex & Diagnosis & $\begin{array}{l}\text { Age at } \\
\text { diagnosis } \\
\text { (years) }\end{array}$ & Treatment & $\begin{array}{l}h G H \\
\text { treatment }\end{array}$ \\
\hline 1 & $F$ & Craniopharyngioma & 9 & $\begin{array}{l}\text { Surgery, } \\
\text { cranial } \\
\text { radiotherapy }\end{array}$ & $\begin{array}{l}\text { Yes } \\
\quad(2 \text { years })\end{array}$ \\
\hline 2 & $\mathbf{M}$ & Craniopharyngioma & 12 & $\begin{array}{l}\text { Surgery, } \\
\text { cranial } \\
\text { radiotherapy }\end{array}$ & $\begin{array}{l}\text { Yes } \\
\quad(6 \text { years })\end{array}$ \\
\hline 3 & $M$ & Craniopharyngioma & 7 & $\begin{array}{l}\text { Surgery, } \\
\text { cranial } \\
\text { radiotherapy }\end{array}$ & $\begin{array}{l}\text { Yes } \\
\quad(7 \text { years })\end{array}$ \\
\hline 4 & $\mathbf{M}$ & Craniopharyngioma & 5 & $\begin{array}{l}\text { Surgery, } \\
\text { cranial } \\
\text { radiotherapy }\end{array}$ & $\begin{array}{l}\text { Yes } \\
\quad(11 \text { years })\end{array}$ \\
\hline 5 & $M$ & Craniopharyngioma & 6 & $\begin{array}{l}\text { Surgery, } \\
\text { cranial } \\
\text { radiotherapy }\end{array}$ & $\begin{array}{l}\text { Yes } \\
\quad(1 \text { year })\end{array}$ \\
\hline 6 & $\mathrm{~F}$ & Astrocytoma & 3 & $\begin{array}{l}\text { Cranial } \\
\text { radiotherapy }\end{array}$ & No \\
\hline 7 & $M$ & Craniopharyngioma & 16 & $\begin{array}{l}\text { Surgery, } \\
\text { cranial } \\
\text { radiotherapy }\end{array}$ & No \\
\hline 8 & $\mathbf{M}$ & $\begin{array}{l}\text { III ventricular } \\
\text { tumour }\end{array}$ & 15 & $\begin{array}{l}\text { Craniospinal } \\
\text { radiotherapy }\end{array}$ & No \\
\hline 9 & $M$ & Suprasellar germinoma & 18 & $\begin{array}{l}\text { Surgery, } \\
\text { radiotherapy }\end{array}$ & No \\
\hline 10 & $\mathrm{~F}$ & Pituitary adenoma & 16 & Surgery & No \\
\hline
\end{tabular}

whom pituitary deficiency was present before completion of puberty.

\section{Subjects and methods}

Sixty patients (33 males, 27 females; aged 50, range 23-76 years) were identified with severe growth hormone deficiency (peak growth hormone response below $5 \mathrm{mU} / \mathrm{l}$ after insulin induced hypoglycaemia) present for at least 12 months and absence of other conditions known to affect BMD. In 10 patients, growth hormone deficiency had been documented before completion of puberty (Tanner stage V). Clinical details of these patients and their treatments are shown in the table. Five patients had received human growth hormone (hGH) $0.25 \mathrm{IU} / \mathrm{kg}$ intramuscularly three times per week for 6 (2-11) years until fusion of the epiphyses. Mean duration of growth hormone deficiency in the 10 patients was 13.8 years $(2-26)$ and all were adequately replaced with thyroxine, adrenal and sex steroids with no evidence of excessive replacement.

A control group of 17 healthy volunteers (12 males, five females) was also studied so that bone density in the patients with growth hormone deficiency before completion of puberty could be compared with that of a younger population matched for age, sex, weight, and height.

BMD expressed as $\mathrm{g} / \mathrm{cm}^{2}$ was measured by dual energy $x$ ray absorptiometry (Lunar DPX) at lumbar vertebrae L2-L4 (referred to as lumbar spine), the femoral neck and at Ward's triangle, a region of the proximal femur consisting predominantly of trabecular bone. All scans were performed and analysed by the same operator. The coefficient of variation for BMD measurement at our institute is $1 \%$ at the lumbar spine and $2 \%$ at the femoral neck.

Comparisons of BMD between different groups of patients and controls were made by two tailed Student's $t$ tests. Correlation coefficients were calculated from regression analysis and used to compare BMD at each site with all other clinical variables. Results are expressed as mean (range) or mean (SEM); $p<0.05$ was considered significant.

\section{Results}

The 10 patients who had been growth hormone deficient during puberty were younger than the 50 adult onset patients $(30.4(1.44) v 50 \cdot 1(1.95)$ years; $p<0.001)$; they had been pituitary deficient for longer $(14 \cdot 9(1.84) v 9 \cdot 4(1.01) ; \mathrm{p}=$ 0.04 ). 


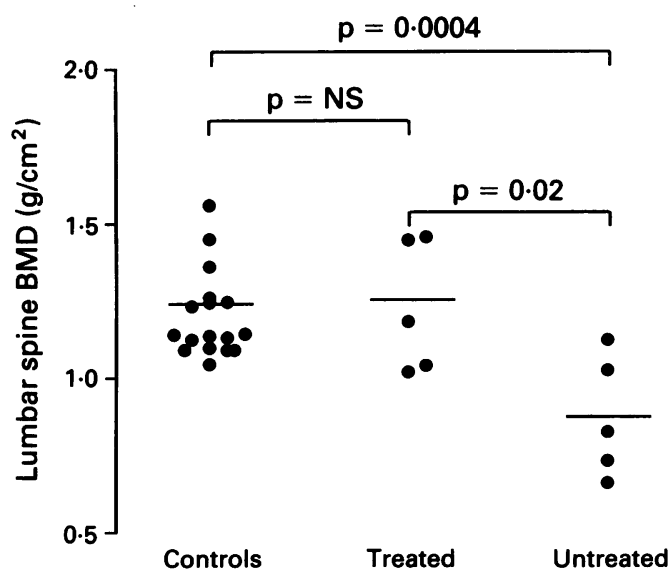

Figure 1 Lumbar spine $B M D\left(\mathrm{~g} / \mathrm{cm}^{2}\right)$ in adult patients with documented growth hormone deficiency during puberty who either were treated or were not treated with $h G H$ compared with healthy controls matched for age, sex, weight, and height.
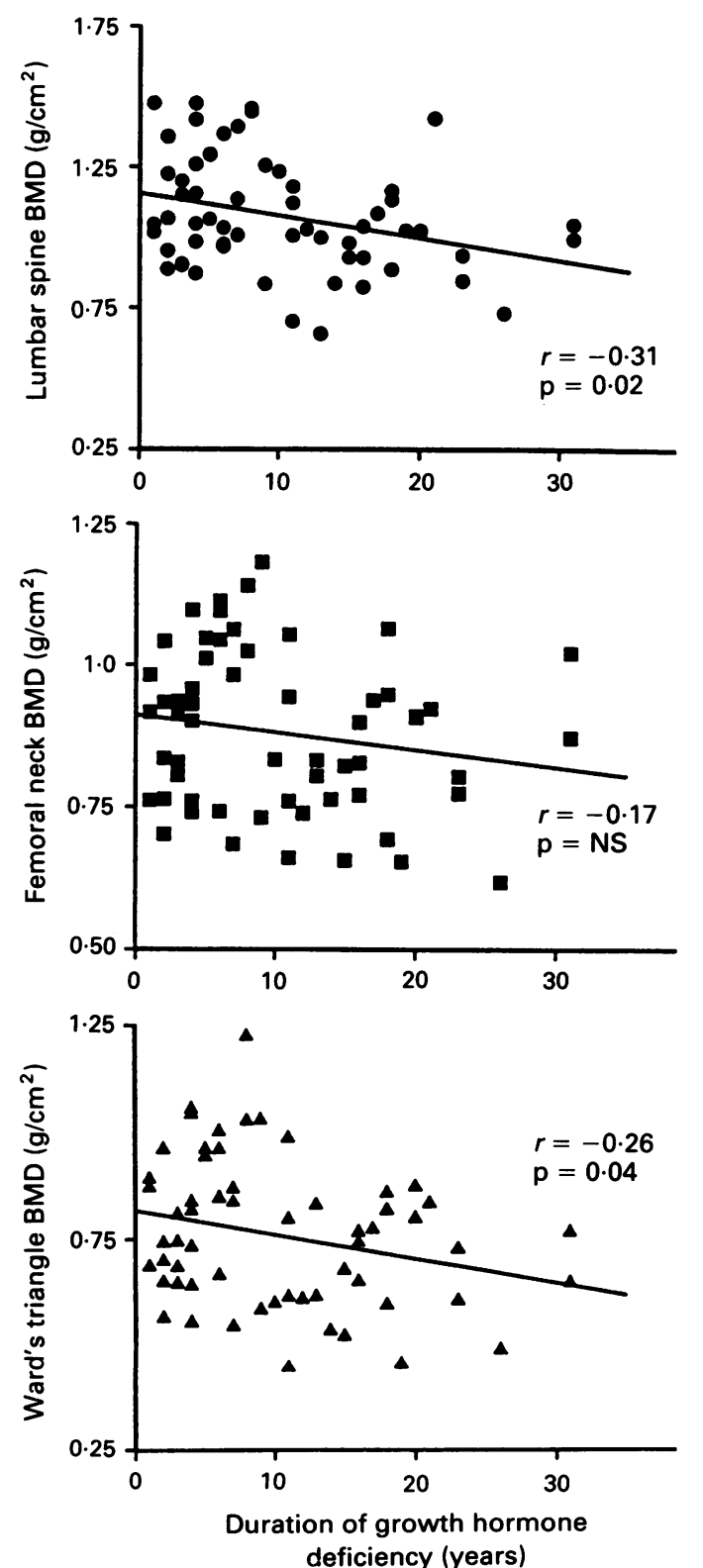

Figure 2 Relation of duration of growth hormone deficiency (years) and BMD at the lumbar spine, femoral neck, and Ward's triangle in 60 adults with growth hormone deficiency.
Growth hormone treated and growth hormoneuntreated patients were similar with respect to the following variables: current age, sex, body mass index, onset and duration of growth hormone deficiency, duration of sex hormone deficiency and replacement. Patients who had not received replacement with hGH during puberty were shorter than those who had received hGH (158.6 (3.57) $v 170.2(2.65) \mathrm{cm}$; $\mathrm{p}=0.03)$. Mean (SEM) BMD $\left(\mathrm{g} / \mathrm{cm}^{2}\right)$ in the five patients with pubertal deficiency not treated with hGH was appreciably reduced compared with normal controls at the lumbar spine: 0.87 $(0.09)$ v $1.20(0.03), \mathrm{p}=0.0004$; femoral neck: $0.81(0.06) v 1.08(0.04), \mathrm{p}=0.004$; and Ward's triangle: $0.68(0.07) v 1.04(0.05), p=0.002$. Values were also reduced compared with those of growth hormone treated patients at the lumbar spine: $0.87 \quad(0.09) \quad v \quad 1.23 \quad(0.09)$, $\mathrm{p}=0.02$; femoral neck: $0.81(0.06) v 0.99(0.05)$, $\mathrm{p}=0.05$; and Ward's triangle: $0.68(0.07) v 0.96$ (0.08), $\mathrm{p}=0.03$ (fig 1 ).

In adult onset growth hormone deficient patients, mean (SEM) BMD $\left(\mathrm{g} / \mathrm{cm}^{2}\right)$ was: lumbar spine $1.08(0.03)$, femoral neck 0.88 $(0.02)$, and Ward's triangle $0.74(0.02)$, which represented $89.9(2 \cdot 2) \%, 96 \cdot 1(1 \cdot 9) \%$, and 96.0 $(2 \cdot 7) \%$ respectively of a normal reference population studied with an identical scanner (Lunar DPX Reference Manual, 1990). Values were similar in males and females.

A significant negative correlation was found between the duration of growth hormone deficiency and BMD measured at the lumbar spine $(r=-0.31 ; p=0.02)$ or Ward's triangle $(r=-0.26 ; \mathrm{p}=0.04)$ but not at the femoral neck (fig 2).

\section{Discussion}

These results indicate that adult BMD is reduced in growth hormone deficient patients when present before completion of puberty and that, importantly, it can be normalised by hGH replacement during this period. This suggests that growth hormone has a pronounced effect on bone density during puberty at the time when peak bone mass is being attained. ${ }^{3}{ }^{4}$ This is consistent with previous reports of reduced radial and spinal bone mass in association with pubertal growth hormone deficiency. ${ }^{15}$

Additionally, growth hormone may be required for maintenance of peak bone mass as we noted a significant negative correlation between BMD and duration of adult onset growth hormone deficiency which was independent of other variables. We do not know if longer follow up in those patients who received hGH during puberty will reveal reduced BMD later in life.

Bone density measured by dual $x$ ray absorptiometry as in this study may be influenced by the size of vertebral body. ${ }^{6}$ It has been estimated that $50 \%$ of the pubertal increase in spine mineral is attributable to bone expansion rather than to an increase in BMD per unit volume.? As patients who had not received hGH during puberty were shorter than growth hormone treated patients, their lower BMD values could 
be, in part, related to their smaller vertebrae. However, this cannot be the whole explanation as BMD in these growth hormone untreated individuals was appreciably reduced compared with normal controls matched for height.

Our patients with pubertal pituitary deficiency had all been conventionally treated with gonadal steroids but some may have experienced a period of sex hormone deficiency before starting treatment. Even a brief period of hypogonadism may be associated with osteopenia. ${ }^{8}$ The action of sex steroids in promoting the acquisition of bone mineral during puberty could require the presence of growth hormone to achieve their full effect. ${ }^{9}$

One patient who did not receive hGH during puberty had been treated with craniospinal irradiation and this could have contributed to his low bone density. Spinal growth during puberty has been shown to be impaired by spinal irradiation. ${ }^{10}$ In such children, treatment with hGH may limit further reduction in height SD scores. ${ }^{11}$

If growth hormone is required for achievement of peak bone mass as suggested by this study, an anabolic rather than antiresorptive action is likely on the basis of in vitro ${ }^{12}$ and in vivo $^{14} 15$ studies of growth hormone and insulin-like growth factor-I on bone metabolism. Interestingly, trabecular bone (lumbar spine, Ward's triangle) appears more sensitive to the effects of growth hormone than cortical bone. Osteoporosis associated with hypercortisolism or oestrogen deficiency also preferentially affects trabecular bone. ${ }^{16} 17$

Our results suggest that the long term consequences of growth hormone deficiency on BMD may be particularly serious in patients who develop pituitary deficiency before attaining peak bone mass. Growth hormone treatment should be considered in all such children to reduce the risk of osteoporosis in adult life.

1 Shore RM, Chesney RW, Mazess RB, Rose PG, Bargman GJ. Bone mineral status in growth hormone deficiency. Y Pediatr 1980;96:393-6.

2 Gilsanz V, Varterasian M, Senec MO, Cann CE. Quantitative spinal mineral analysis in children. Ann Radiol 1986;29: $380-2$.

3 Riggs BL, Wahner HW, Seeman E, et al. Changes in bone mineral density of the proximal femur and spine with mineral density of the proximal

4 Gigeing. C Clin Invest 1982 , Carlson M, Boechet MI, Cann CE, Schultz EE. Peak trabecular vertebral density: a comparison Schultz EE. Peak trabecular vertebral density: a comparison of adolesc $260-2$.

5 Kaufman J-M, Taelman P, Vermeulen A, Vandeweghe $M$. Bone mineral status in growth hormone-deficient males with isolated and multiple pituitary deficiencies of childhood onset. F Clin Endocrinol Metab 1992;74:118-23.

6 Glastre C, Braillon P, David L, Cochat P, Meunier PJ, Delmas PD. Measurement of bone mineral content of the lumbar spine by dual energy $x$-ray absorptiometry in normal children: correlations with growth parameters. $f$ Clin Endocrinol Metab 1990;70:1330-3.

7 Katzman DK, Bachrach LK, Carter DR, Marcus R. Clinical and anthropometric correlates of bone mineral acquisition in healthy adolescent girls. $f$ Clin Endocrinol Metab 1991; 73:1332-9.

8 Arisaka O, Arisaka M, Hosaka A, Yabuta K. Bone mineral status in hypopituitarism. Am $\mathcal{F}$ Dis Child 1989;143:272-3.

9 Job JC. Results of long term growth hormone replacement therapy in children: when and how to treat? Horm Res therapy in children: when

10 Shalet SM. Endocrine consequences of treatment of malignant disease. Arch Dis Child 1989;64:1635-41.

11 Clayton PE, Shalet SM, Price DA. Growth responses to growth hormone therapy following craniospinal irradiation. Eur I Pediatr 1988;147:597-601.

12 Canallis E, McCarthy T, Centrella $M$. Growth factors and regulation of bone remodelling. $\mathcal{f}$ Clin Invest 1988;81: 277-81.

13 Stracke H, Schultz A, Moeller D, Rossol S, Schatz H. Effect of growth hormone on osteoblasts and demonstration of somatomedin-C/IFG-I in boneorgan culture. Acta Endocrinol (Copenh) 1984;107:16-24.

14 Van der Veen EA, Netelenbos JC. Growth hormone (replacement) therapy in adults: bone and calcium metabolism. Horm Res 1990;33 (suppl 4):65-8.

15 Spencer EM, Liu CC, Si ECC, Howard GA. In vivo action of insulin-like growth factor-I (IGF-I) on bone formation and insulin-like growth factor-1 (IGF-1) on

16 Klibanski A, Biller BMK, Rosenthal DI, Schoenfeld DA, Saxe V. Effects of prolactin and oestrogen deficiency in amenorrheic bone loss. $\mathcal{F}$ Clin Endocrinol Metab 1988;67: 124-30.

17 Hahn TJ, Boisseau VC, Avioli LV. Effect of chronic corticosteroid administration on diaphyseal and metaphyseal bone mass. $\mathcal{~ f ~ C l i n ~ E n d o c r i n o l ~ M e t a b ~ 1 9 7 4 ; 3 9 : 2 7 4 - 8 2 . ~}$ 